\section{MANDATARIOS (A)TÍPICOS: TRAYECTORIAS POLÍTICAS DE DOS GOBERNADORES DESTITUIDOS}

\author{
(A) TYPICAL LEADERS: \\ POLITICAL TRAJECTORIES OF \\ TWO IMPEACHED GOVERNORS \\ CINTIA RODRIGO •
}

\begin{abstract}
Cintia Rodrigo es docente de la Universidad Nacional de Mar del Plata e Investigadora Asistente del CONICET (Argentina), con sede en el Departamento de Historia de la Facultad de Humanidades de la misma universidad.
\end{abstract}

\section{Resumen}

En este artículo se reconstruyen las trayectorias de dos gobernadores de la provincia de San Juan (Argentina) que comparten el destino de haber sido destituidos mediante juicio político. Se trata de Jorge Escobar (1991-1992) y Alfredo Avelín (1999-2002). El objetivo es describir qué rasgos relativamente típicos encarnaba cada uno de estos dirigentes que los hicieron «elegibles» como gobernadores. El trabajo presenta un apartado para las características biográficas de cada uno de ellos, siguiendo un orden cronológico de las sucesivas posiciones que ocuparon desde sus grupos familiares hasta el máximo cargo electivo del ámbito provincial.

\section{Abstract}

This paper reconstructs the trajectories of two governors of San Juan province (Argentina). Those governors have been both removed by impeachment. They are Jorge Escobar (1991-1992) and Alfredo Avelin (1999-2002). The aim is to describe what relatively typical atributtes embodied each of these political leaders. In other words, describe those atribbutes which made them «eligible» as governors. The paper presents a section for biographical characteristics of each of them. Following a chronological order, this article describes the successive positions occupied by them, starting from their family groups to the maximum provincial elective position. 